\title{
Determination of indinavir in human plasma and its use in pharmacokinetic study
}

\author{
Talita Mota Gonçalves, Breno Xavier Fernandes Pires, Danilo César Galindo Bedor, Vanessa \\ Cristina de Souza, Luis Renato Pires de Abreu, Davi Pereira de Santana*
}

Centro de Biodisponibilidade/ Bioequivalência, Núcleo de Desenvolvimento Farmacêutico e Cosmético (NUDFAC), Departamento de Ciências Farmacêuticas, Universidade Federal de Pernambuco

*Correspondence:

D. P. Santana

Núcleo de Desenvolvimento

Farmacêutico e Cosmético (NUDFAC)

Departamento de Ciências

Farmacêuticas

Universidade Federal de Pernambuco.

Av. Professor Arthur de Sá s/n, Cidade

Universitária

50740-520 - Recife - PE, Brasil

E-mail address: d-santana@bol.com.br
We report the development and validation of a new sensitive, accurate and precise HPLC method with ultraviolet detection for the determination of indinavir sulfate (IND) in human plasma and its application to a bioequivalence study of a new generic formulation. The extraction of IND from plasma samples was achieved by using liquid-liquid extraction with a mean recovery of $73.9 \%$. The lower limit of quantification was $0.05 \mu \mathrm{g} / \mathrm{mL}$. Bioequivalence between the products was determined by calculating $90 \%$ confidence intervals (CI) for the ratio of $C_{\text {max }}{ }^{2}$ $A U C_{0-t}$ and $A U C_{0-\text { inf }}$ values for the test and reference products, within the 0.80-1.25 interval proposed by ANVISA and FDA. Therefore the medications are bioequivalent and inter-exchangeable.

\section{INTRODUCTION}

The use of generic drugs can improve health pattern and life quality through a larger number of people consuming cheaper drugs. For antiretroviral agents in particular, it means an extraordinary progress for the human rights and health equity, especially in developing countries.

Generic drugs are available to the Brazilian population since 1999 when the Act 9.787 was established, following the conceptual model adopted by European countries, the United States, Canada and recommended by the World Health Organization (WHO). The generic drugs policy improved control of drug prices practiced by Pharmaceutical Industries in Brazil, allowed effective market competition, as well as the selection of reference products and priorities for generics production. In addition, quality, safety and efficacy requisites were revised including the more stringent monitoring of Good Manufacturing Practices (GMP) in the pharmaceutical industry and regular control of drug quality (Storpirtis et al, 2004).

Indinavir sulfate (CAS 157810-81-6), chemically designated as (alpha-R, gamma-S, 2S)-alpha-benzyl-2(tert-butylcarbamoyl) - gamma - hydroxyl - $N$ - [(1S, 2R)2-hydroxy-1 -indanyl]-4-(3 -pyridylmethyl)-1 piperazinevaleramide sulfate (1:1) (salt), is a selective, competitive, reversible inhibitor of HIV protease, an enzyme that plays an essential role in HIV replication and in the formation of infectious virus. Indinavir (Figure 1) is a structural analog of HIV Phe-Pro protease cleavage site (Jayewardene et al., 1998; Zhong, Yeh, 1999; Turner et al., 2003; Justesen et al., 2003).

The drug structure inhibits the function of HIV protease, blocking virus maturation and causing the 
formation of immature, noninfectious virions. Indinavir is active in both acutely and chronically infected cells while nucleoside reverse transcriptase inhibitors (NRTIs) do not affect chronically infected cells (Woolf et al., 1997; Jayewardene et al., 1998; Foisy, Sommadossi, 1999; Lin, 1999; Rose et al., 2000; Turner et al., 2003; Justesen et al., 2003). While indinavir does not affect early stages of the HIV replication cycle, it does interfere with the production of infectious HIV, limiting further infectious spread of the virus. In vitro studies indicate that the antiretroviral effects of HIV protease inhibitors and some NRTIs or Nonnucleoside reverse transcriptase inhibitors (NNRTIs) may be additive or synergistic (Burger et al., 1997; Aymard et al., 2000; Yamada et al., 2001; Justesen et al., 2003; Hurwitz, Schinazi, 2002; Chi et al., 2002; Rentsch, 2003). It is rapidly absorbed in the fasted state, with peak plasma concentration of $0.8 \pm 0.3$ hours (Lin, 1997; Yeh et al., 1999; Raffani, Haas, 2003).

Indinavir has been detected in low concentrations in cerebrospinal fluid of adults and children receiving the drug (Lin, 1997; Zhong Yeh, 1999; Hass et al., 2000; Svensson et al., 2000; Megard et al., 2002). Protein binding of indinavir is approximately $60 \%$ over a range of 0.05 to $10 \mu \mathrm{g} / \mathrm{mL}$ (Raffani, Haas, 2003; Schon et al., 2003). Indinavir is mainly metabolized by the liver (Woolf et al., 1997; Rentsch, 2003; Lin, 1997; Langmann et al., 1999; Justesen et al., 2003; Raffani, Haas, 2003). Plasma halflife averages 1.8 hours in adults and 1.1 hours in children (Lin, 1997). Indinavir is excreted primarily in the faeces both as unaltered drug and as metabolites. Following a 400 $\mathrm{mg}$ oral dose, $83 \%$ were recovered in faeces $(19.1 \%$ as unchanged drug) and 19\% were recovered in urine (9.4\% as unchanged drug) (Raffani, Haas, 2003).

Several high-performance liquid-chromatographic (HPLC) assays, using UV detection, have been reported for the determination of indinavir in serum/plasma (Heeswijk et al, 1998; Hugen et al., 1999; Svensson et al., 2000; Dailly et al., 2001; Sarasa-Nacenta et al., 2001; Villani et al., 2001; Marzolini et al., 2002; Turner et al., 2003) either alone (Rose et al., 2000; Justsen et al., 2003), or together with its metabolites (Langman et al., 1999; Hurwitz, Schinazi, 2002). However, the need for a time and costsaving method meeting the current GLP guidelines for the analysis of indinavir in human plasma, stimulated us to investigate the usefulness of a new simple and fast method with sensitivity and selectivity appropriated to perform the quantification of indinavir in human plasma.

This paper describes the development and validation of an accurate, precise, specific, sensitive and inexpensive HPLC method for indinavir quantification in human plasma using verapamil as internal standard (I.S.), and its application to a bioequivalence study between two pharmaceutical products containing indinavir available in the Brazilian market.
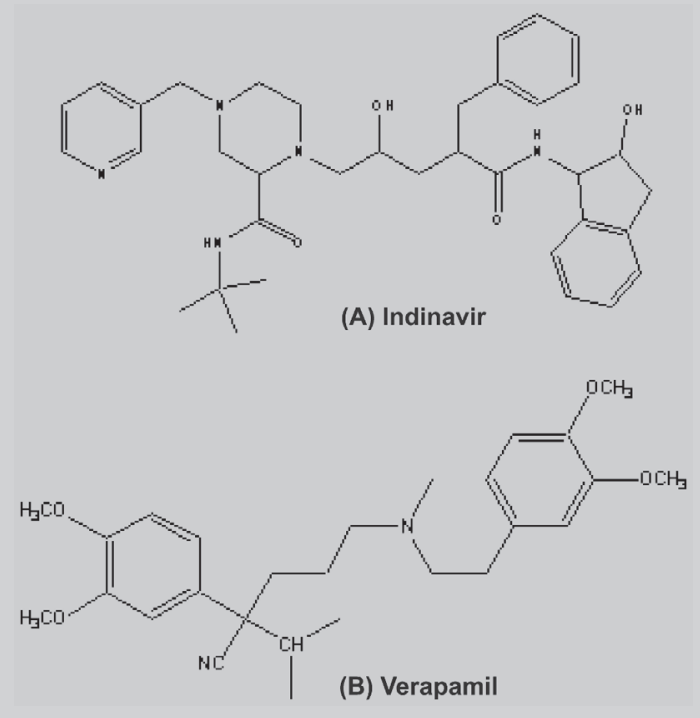

FIGURE 1 - Chemical structures of indinavir (A) and verapamil (B) used as an internal standard.

\section{EXPERIMENTAL}

\section{Drugs and Chemicals}

Acetonitrile (ACN) was purchased from EM Science (Gibbstown, NJ, USA); Methyl tert-butyl ether (MTBE) was purchased from Mallinckrodt Baker (Phillipsburg, NJ, USA). Methanol, sodium hydroxide and phosphoric acid, ammonium chloride and di-sodium hydrogen phosphate were purchased from Merck (Rio de Janeiro, RJ, Brazil). Acetonitrile and methanol were used as HPLC grade solvents and all other reagents as analytical grade.

Indinavir was obtained from Hetero drugs (Hyderabad, India), verapamil (internal standard) was purchased from Sigma Chemicals (St Louis, MO, USA). Ultra pure water was prepared using Milli-Q (Millipore, Molsheim, France). Blank human blood was collected from healthy, drug-free volunteers. Plasma was obtained by centrifugation of blood treated with an anticoagulant. Plasma was prepared and stored at approximately $-20{ }^{\circ} \mathrm{C}$.

\section{Instruments and chromatographic conditions}

The HPLC analysis were performed on a Shimadzu chromatographic system (Kyoto, Japan) composed by a LC-10AD VP pump, a SIL-10A VP auto-sampler, a SPD10A VP UV detector and a SCL 10 A-VP controller unit. 
The analytical column used was a Phenomenex Luna ${ }^{\circledR} \mathrm{C} 8$ $10 \mathrm{~mm}, 250 \times 4.6 \mathrm{~mm}$, Securityguard ${ }^{\circledR}$ guard column (Torrance, USA). Acquired data was processed with CLASS-VP (v.6.2) software running under Windows 98 on a Pentium PC. The mobile phase was a mixture of disodium hydrogen phosphate $(0.01 \mathrm{M})+$ ammonium chloride $(0.4 \%)$ with $\mathrm{pH}$ adjusted to 4.5 (solvent $\mathrm{A}$ ) and $\mathrm{ACN}$ (solvent B), 68:32, v/v, pumped at a flow rate of 1.8 $\mathrm{mL} / \mathrm{min}$ through the column. Peaks were monitored at 210 $\mathrm{nm}$ at $30{ }^{\circ} \mathrm{C}$. Quantification of indinavir was done by measuring the response (area) of indinavir in relation to the response of ritonavir (internal standard).

\section{Standard solutions}

Stock solutions of indinavir $(1 \mathrm{mg} / \mathrm{mL})$ were prepared in methanol-water $(1: 1, \mathrm{v} / \mathrm{v})$. Working standard solutions were prepared from the stock solution by sequential dilution with $\mathrm{ACN}$ - water $(1: 1, \mathrm{v} / \mathrm{v})$ to yield final concentrations of 1,10 and $100 \mu \mathrm{g} / \mathrm{mL}$.

Stock solutions of the I.S. $(1 \mathrm{mg} / \mathrm{mL})$ were prepared in methanol. Working internal standard solutions were prepared from the stock solution by sequential dilution with methanol to yield final concentrations of 1,80 and $100 \mu \mathrm{g} / \mathrm{mL}$. Stock and working standard solutions were protected from light and stored at $-20^{\circ} \mathrm{C}$ until used. Calibration standards were obtained by adding known amounts of indinavir to drug-free plasma to achieve concentrations of $0.01,0.02,0.05,0.1$, $0.2,0.5,1,2,5,10$ and $15 \mu \mathrm{g} / \mathrm{mL}$. Three quality controls of low $(0.15 \mu \mathrm{g} / \mathrm{mL})$, middle $(4.5 \mu \mathrm{g} / \mathrm{mL})$ and high $(9.0 \mu \mathrm{g} / \mathrm{mL})$ concentrations were prepared by adding known amounts of indinavir to drug-free plasma. Plasma solutions were protected from light and stored at $-70{ }^{\circ} \mathrm{C}$ until used.

\section{Extraction procedure for indinavir and verapamil (I.S.) from plasma}

Indinavir and I.S. were extracted from human plasma samples by liquid-liquid extraction. Calibration standards, validation control samples and volunteers' plasma samples were prepared by aliquoting $250 \mu \mathrm{L}$ of plasma. The plasma sample was transferred to a $2 \mathrm{~mL}$ polypropylene screw capped tube and $20 \mu \mathrm{L}$ of internal standard solution $(80 \mu \mathrm{g} / \mathrm{mL})$ was added. The contents of the tubes were mixed by vortexed and $1 \mathrm{~mL}$ of the extraction solvent (MTBE) was added. After vortexing ( $5 \mathrm{~min}$ ), tubes were centrifuged ( $5000 \mathrm{rpm}$ for $5 \mathrm{~min}$ ). The tubes were then placed in dry ice-acetone bath, the lower aqueous layers were frozen, and the organic phase was transferred to clean $10 \mathrm{~mL}$ glass tubes. The solvent was evaporated under a stream of nitrogen at $40{ }^{\circ} \mathrm{C}$. The resulting residue was reconstituted in $150 \mu \mathrm{L}$ of the mobile phase: $100 \mu \mathrm{L}$ aliquot of the supernatant was transferred to the injection vials and $50 \mu \mathrm{L}$ were injected into the chromatographic system. The quality controls samples were analyzed in duplicate for each batch. All samples from a single volunteer were analyzed in the same day in order to avoid inter-assay variation.

\section{Method validation}

The specificity of the method was determined by comparing chromatograms obtained from plasma containing indinavir and I.S. with those obtained from blank samples. Possible interference from other drugs was investigated by examining their peak separation from indinavir using the same HPLC conditions.

The lower limit of quantification (LLOQ) was the smallest analytical concentration which could be measured with precision and accuracy.

In order to perform the analysis of indinavir in human plasma, the analytical recovery of indinavir was determined at concentrations of $0.15,4.5$, and $9.0 \mu \mathrm{g} / \mathrm{mL}(\mathrm{n}=5)$. Drugfree plasma was spiked with known amounts of the drug to achieve the concentration previously specified. These samples were processed by the analytical method described above and peak areas were compared with that obtained by direct injection of the drugs in the mobile phase.

To assess linearity, study was carried out in the range of 0.01 to $15 \mu \mathrm{g} / \mathrm{mL}$. The linearity test was done by spiking drug-free plasma with known amounts of the drug to achieve the concentrations of $0.01,0.02,0.05,0.1,0.2,0.5,1,2,5$, 10 and $15 \mu \mathrm{g} / \mathrm{mL}$.

In order to perform the analysis of indinavir in human plasma, the precision and accuracy or data were obtained by analyzing aliquots of three-spiked plasma samples at low $(0.15 \mu \mathrm{g} / \mathrm{mL})$ middle $(4.5 \mu \mathrm{g} / \mathrm{mL})$ and high $(9.0 \mu \mathrm{g} /$ $\mathrm{mL}$ ) concentration levels of indinavir. Intra-day reproducibility was determined by analyzing 5 aliquots of spiked human plasma and inter-day reproducibility was determined over 3 consecutive days.

Standard solutions were stored at room temperature and at $4{ }^{\circ} \mathrm{C}$. These samples were used to investigate the stability of indinavir over a period of 1 week. Drug-free plasma was spiked with known amounts of the drug to achieve concentrations of $0.15,4.5$ and $9.0 \mu \mathrm{g} / \mathrm{mL}(\mathrm{n}=5)$. They were stored at $-70{ }^{\circ} \mathrm{C}$. These samples were used to investigate the long-term stability of indinavir over a period of 9 months. In addition, short-term stability studies of plasma samples spiked with indinavir were performed for 6 hours period at room temperature storage and for three freeze-thaw cycles. 


\section{Bioequivalence study}

The analytical method was applied to evaluate the bioequivalence of two capsule formulations of indinavir in healthy volunteers: Crixivan ${ }^{\circledR}$ capsules $400 \mathrm{mg}$ (standard reference formulation) and indinavir capsules $400 \mathrm{mg}$ (test formulation).

Twenty-six adult volunteers, with an average age of 23 years, average height of $1.75 \mathrm{~m}$ and average body weigh of $74.22 \mathrm{~kg}$ and with $15 \%$ of the ideal body mass, were selected for the study after assessment of their health status by clinical evaluation (physical examination, ECG) and the following laboratory tests: blood glucose, urea, creatinine, aspartate aminotransferase (AST), alanine aminotransferase (ALT), alkaline phosphatase, $\gamma$-gluthamil transferase $(\gamma-\mathrm{GT})$, total bilirubin, albumin and total protein, triglyceride, total cholesterol, hemoglobin, hematocrit, total and differential white cell counts, and routine urinalysis. All volunteers were negative for human immunodeficiency virus (HIV), hepatitis $\mathrm{C}$ virus (HCV), and hepatitis B virus (HBV), except for serological scar. The volunteers were free from significant cardiac, hepatic, renal, pulmonary, gastrointestinal, neurological and hematological disease as determined within four weeks before the beginning of the study. All volunteers gave written consent and the Ethical Committee of Universidade Federal de Pernambuco approved the clinical protocol.

The study was an open, single dose, randomized, two-period crossover trial with a 1 -week washout period. The volunteers were hospitalized, had a regular meal and received a $400 \mathrm{mg}$ capsule of the formulation. After administration of the coated tablet, the volunteers were asked to drink $300 \mathrm{~mL}$ of water. Blood samples for plasma drug assay were taken from a forearm vein before indinavir administration and at $0.25,0.5,0.75,1.0,1.25,1.5,2.0$, 2.5, 3.0, 4.0, 6.0, 8.0 and 12 hours after it. Heparinized venous blood samples $(8 \mathrm{~mL})$ were collected by means of an indwelling venous canula. The blood samples were centrifuged at $2000 \mathrm{~g}$ for ten minutes and the plasma removed and stored at $-70^{\circ} \mathrm{C}$ until assayed. The volunteers received a standard meal five hours after dosing. Six hours after dose administration a standard lunch was available. Liquids were allowed ad libitum after lunch, but xanthinecontaining foods and beverages, such as tea, coffee and cola were not permitted $48 \mathrm{~h}$ prior to each dosing and until the collection of the last blood sample.

\section{Pharmacokinetic and statistical analysis}

Bioequivalence between the two formulations was assessed by calculating individual test/reference ratios for the peak of concentration $\left(\mathrm{C}_{\max }\right)$, area under curve (AUC) of plasma concentration until the last concentration observed $\left(\mathrm{AUC}_{0-t}\right)$, and the area under curve between the first sample (pre-dosage) and infinite $\left(\mathrm{AUC}_{0 \text {-inf }}\right)$. The $\mathrm{C}_{\max }$ and the time taken to achieve this concentration $\left(\mathrm{T}_{\max }\right)$ were obtained directly from the curves. The areas under the indinavir plasma concentration vs. time curves from 0 to the last detectable concentration $\left(\mathrm{AUC}_{0-\mathrm{t}}\right)$ were calculated by applying the linear trapezoid rule. Extrapolation of these areas to infinity $\left(\mathrm{AUC}_{0 \text {-inf }}\right.$ ) was done by adding the value $\mathrm{C}_{\text {last }} /$ ke to the calculated $\mathrm{AUC}_{\text {last }}$ (where $\mathrm{C}_{\text {last }}=$ the last detectable concentration, and $\mathrm{ke}=$ the first-order terminal elimination rate constant which was estimated by linear regression from the points describing the elimination phase on a log-linear plot). The AUC and $\mathrm{C}_{\max }$ data for the two formulations were analyzed by analysis of variance (ANOVA) to establish whether the $90 \%$ confidence interval (CI) of the ratios was within the $80-125 \%$ interval indicating bioequivalence as proposed by the US Food and Drug Administration. Parametric and non-parametric analysis of indinavir transformed arithmetic means and individual $\mathrm{T}_{\max }$ differences between test and reference formulations were performed.

\section{RESULTS}

\section{Validation of HPLC method}

The alternative HPLC-UV method described, validated and used here for drug quantification, provides adequate sensitivity, specificity and high sample throughput required for pharmacokinetic studies.

Figure 2 shows the described chromatographic conditions, the retention times for indinavir and I.S. were 10.6 and $12.8 \mathrm{~min}$, respectively, at a flow rate of $1.8 \mathrm{~mL} /$ min. It also shows that no endogenous interfering peaks appeared at the retention times of the compounds of interest.

The average absolute recovery of indinavir in plasma was $73.9 \%$. The LLOQ for indinavir was $0.05 \mu \mathrm{g} / \mathrm{mL}$. The lower limit of quantification was $0.05 \mu \mathrm{g} / \mathrm{mL}$, with relative standard deviation lower than $10 \%$. The calibration curve was linear over the range $0.05 \mu \mathrm{g} / \mathrm{mL}$ to $15.0 \mu \mathrm{g} / \mathrm{mL}$, with a regression coefficient $\geq 0.99$ and intercept not significantly different from zero (Figure 3 ).

The obtained analytical precision and accuracy for intra-day and inter-day assays of three quality controls $(0.15,4.5$ and $9.0 \mu \mathrm{g} / \mathrm{mL})$ are presented in Table I. The overall variability of the quality controls $(0.15,4.5$ and 9.0 $\mu \mathrm{g} / \mathrm{mL} ; \mathrm{n}=52$ ) was $6.2,2.7$ and $5.1 \%$, respectively; the accuracy was $100.4,99.9$ and $99.9 \%$, respectively. No 

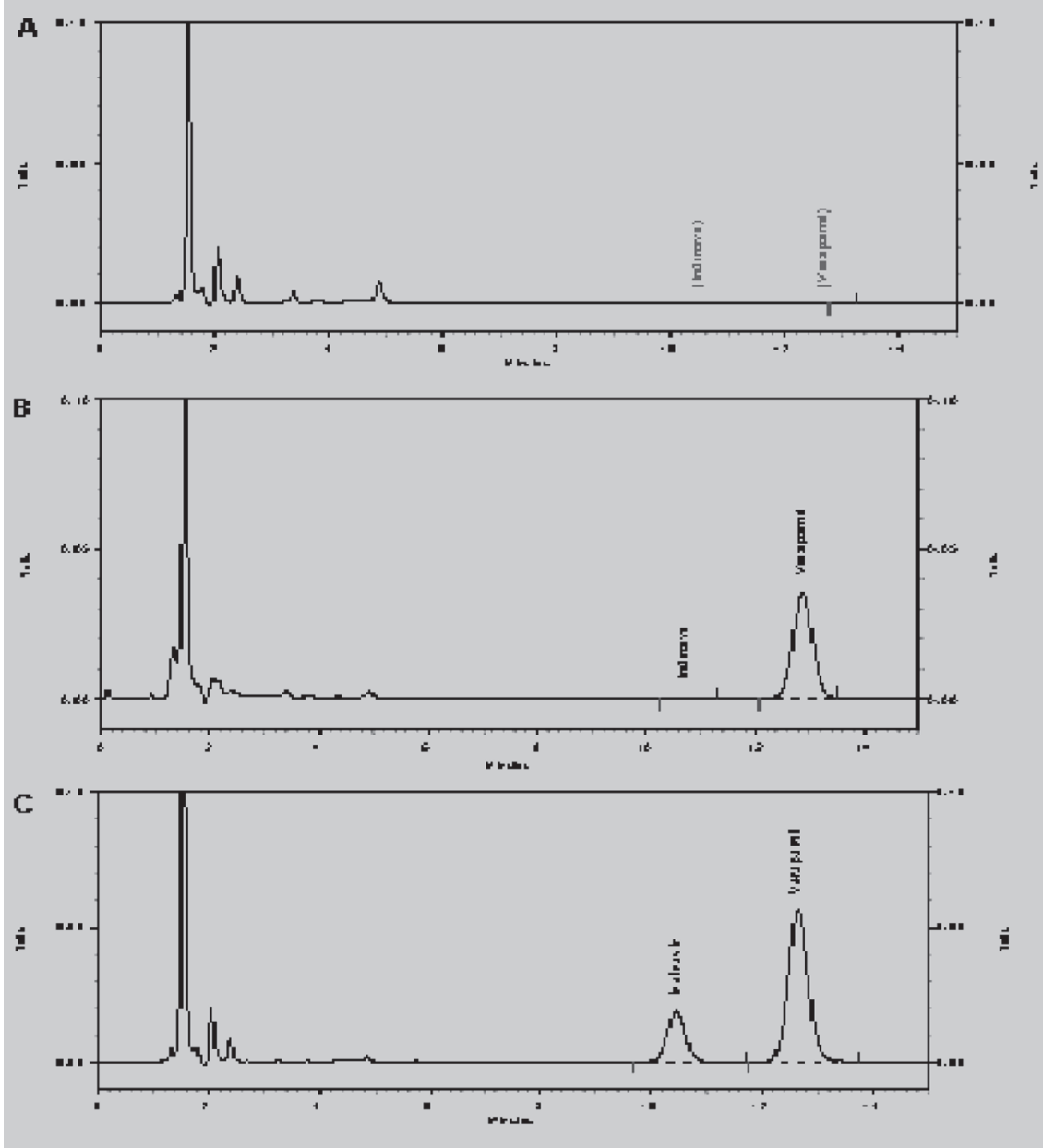

FIGURE 2 - Typical chromatographic of(A) blank human plasma; (B) blank human plasma spiked with indinavir (0.05 $\mu \mathrm{g} / \mathrm{mL}$ ) and internal standard (verapamil, $16 \mu \mathrm{g} / \mathrm{mL}$ ); (C) plasma from healthy volunteer after oral administration of 400 $\mathrm{mg}$ of indinavir, spiked with internal standard (verapamil $16 \mu \mathrm{g} / \mathrm{mL}$ ).

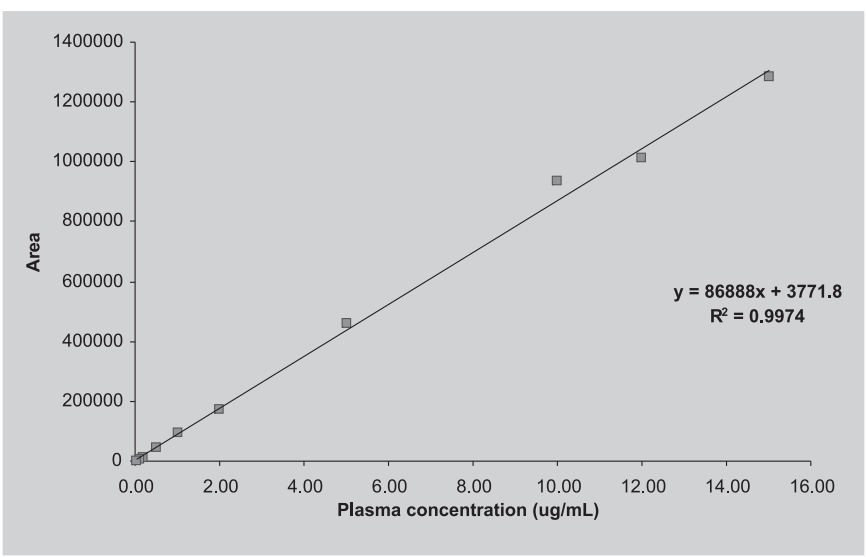

FIGURE 3 - Standard calibration curve for indinavir quantification in human plasma by HPLC method with UV detection.

significant degradation of indinavir was observed during this period under storage conditions.
Organic extracts were stable at room temperature for at least 48 hours. Plasma samples were stable for at least 270 days at $-70{ }^{\circ} \mathrm{C}$ and also after three freeze-thawing cycles.

These results indicate that analyte is stable in human plasma and makes it an acceptable method for bioequivalence studies.

\section{Bioequivalence evaluation}

Safety was evaluated by monitoring adverse events and vital signs and through physical examination, clinical laboratory tests and electrocardiograms. Each volunteer was questioned periodically throughout the study regarding adverse effects.

Indinavir was well tolerated at the administered dose, and no adverse effects were reported. Mean indinavir plasma concentration-time profiles and average values of pharmacokinetic parameters after test and reference products administration obtained after $400 \mathrm{mg}$ of indinavir 
TABLE I - Analytical precision and accuracy of the HPLC determination of indinavir from spiked plasma samples $(n=5)$ - Intra- and Inter-day variation

\begin{tabular}{lccc}
\hline $\begin{array}{l}\text { Nominal } \\
\text { concentration } \\
(\mu \mathrm{g} / \mathrm{mL})\end{array}$ & $\begin{array}{c}\text { Concentration } \\
\text { Obtained Mean } \\
(\mu \mathrm{g} / \mathrm{mL}) \pm \mathrm{SD}\end{array}$ & $\begin{array}{c}\text { Precision } \\
(\%)\end{array}$ & $\begin{array}{c}\text { Accuracy } \\
(\%)\end{array}$ \\
\hline Intra-day & & & \\
\hline 0.15 & $0.16 \pm 0.006$ & 4.17 & 110.3 \\
4.50 & $4.66 \pm 0.29$ & 6.27 & 103.5 \\
9.00 & $9.69 \pm 0.57$ & 5.94 & 107.7 \\
\hline Inter-day & & & \\
\hline 0.15 & $0.15 \pm 0.01$ & 8.28 & 100.9 \\
4.50 & $4.44 \pm 0,21$ & 4.88 & 98.7 \\
9.00 & $9.06 \pm 0.66$ & 7.3 & 100.7 \\
\hline
\end{tabular}

TABLE II - Mean pharmacokinetics parameters obtained in 26 healthy volunteers after the administration of indinavir $400 \mathrm{mg}$ test and standard formulations

\begin{tabular}{lcc}
\hline Pharmacokinetics parameters (IC 90\%) & \multicolumn{2}{c}{ Indinavir } \\
& (TEST) & (STD) \\
\hline $\mathrm{AUC}_{0-24 \mathrm{~h}}\left(\mathrm{mg}^{*} \mathrm{~h}^{*} \mathrm{~mL}^{-1}\right)$ Geometric Mean & 5.24 & 4.94 \\
$\mathrm{AUC}_{0 \text {-inf }}\left(\mathrm{mg}^{*} \mathrm{~h}^{*} \mathrm{~mL}^{-1}\right)$ Geometric Mean & 5.47 & 5.22 \\
$\mathrm{C}_{\text {max }}\left(\mathrm{mg}^{*} \mathrm{~mL}^{-1}\right) \mathrm{Geometric} \mathrm{Mean}$ & 3.49 & 3.43 \\
$\mathrm{t}_{1 / 2}(\mathrm{~h})$ Geometric Mean & 1.35 & 1.42 \\
$\mathrm{~T}_{\max }(\mathrm{h})$ Median & 0.75 & 0.75 \\
\hline
\end{tabular}

to 26 healthy human volunteers are shown in Figure 4 and Table II, respectively. The power of statistical test was $>80 \%$ for $\mathrm{AUC}_{0-\mathrm{t}}, \mathrm{AUC}_{0 \text {-inf }}$ and $\mathrm{C}_{\text {max }}$

\section{DISCUSSION}

The HPLC method used here proved to be simple, fast, reliable, selective, sensitive and economic enough to be used in clinical pharmacokinetic studies of indinavir in humans. A bioavailability study involving the standard indinavir formulation was initially conducted to verify the usefulness of the developed method. Once the methods were successfully applied, a full bioequivalence study was carried out.

Several high-performance liquid chromatography (HPLC) methods have been reported for the determination of indinavir levels in animal and human plasma. These methods use gradient HPLC or HPLC with column switching and liquid chromatography - mass spectrometry (Jayewardene et al., 1998, 2001). These assay methods are relatively time-consuming or they use expensive instrumentation not readily accessible to many groups. Furthermore these methods presented a small calibration range. Therefore, our goal was to develop a relatively rapid and costless assay that could be performed at any laboratory with adequate HPLC instrumentation.

Jayewardene et al. (1998) described a simple and reproducible method for monitoring indinavir levels in human plasma, with ether extraction and direct UV detection. The overall recovery of indinavir from human plasma during extraction prior to analysis was $91.4 \%$, in the range 0.25 $5.00 \mu \mathrm{g} / \mathrm{ml}$, indicating good precision and accuracy. However, the data reported suggest that the reproducibility at low levels was not fully satisfactory and the run time was about $30 \mathrm{~min}$. The coefficient of variation of the peak height ratio was $11 \%$ for $0.075 \mu \mathrm{g} / \mathrm{mL}$ (six replicates).

Foisy et al. (1999) described a rapid and sensitive method consisting of solid-phase extraction and separation on a reversed-phase $\mathrm{C} 8$ column using a simple binary mobile phase of phosphate buffer - ACN (60:40, v/v) and HPLC analysis with UV detection at $210 \mathrm{~nm}$, with a LLOQ of 0.025 $\mu \mathrm{g} / \mathrm{mL}$. However, the use of solid phase extraction increases the total cost of the analysis, especially when a large number of samples were analyzed (Jayewardene et al., 1998).

These difficulties prompted us to develop a new simple and fast method with sensitivity and selectivity appropriated to perform the quantification of indinavir in human plasma, meeting the GLP guidelines for bioavailability and bioequivalence studies (FDA, 1993, 1998 a,b).

The HPLC method described here was accurate, precise, sensitive and capable of determining concentrations of indinavir in small volumes of human plasma. The extraction procedure described is simple and a commercially available I.S. (verapamil) was used. However, different extraction procedures were initially tested. Solid phase extraction with C18 extraction cartridges were investigated. Although the extraction using $\mathrm{C} 18$ cartridges proved to be reproducible and the extraction efficiency was higher than $80 \%$, manual SPE is laborious and automated SPE systems are expensive and not readily available. Furthermore the costs related to the SPE cartridges are prohibitive to many laboratories.

Liquid phase extraction methods using low amounts of different organic solvents were then tried, and clean blank chromatograms were obtained. Liquid phase extraction method using MTBE showed the best results, yielding clean extracts with a run time of $15 \mathrm{~min}$.

Mean plasma decay curves (Figure 4) and pharmacokinetic parameters (Table II) obtained for the test product were similar to those obtained for the reference product (Crixivan $\left.{ }^{\circledR}\right)$. The results of ANOVA revealed the absence of period, group and product effects and the power of 


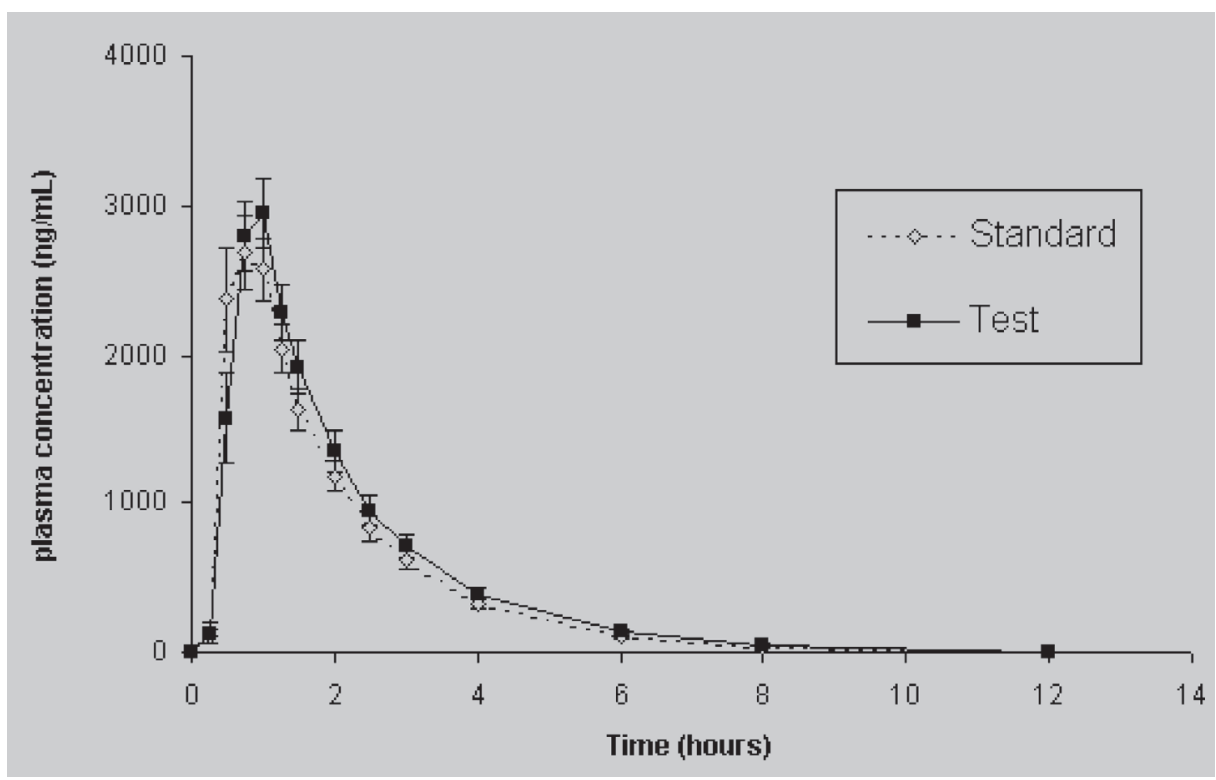

FIGURE 4 - Average indinavir plasma concentration-time profiles after test and reference products administration to 26 healthy human volunteers. Bars indicate mean standard error.

statistical test indicates that the sample size $(n=26)$ was adequate. The $90 \%$ confidence intervals for $\mathrm{AUC}_{0-\mathrm{t}}(0.95-$ $\left.1.18 \mathrm{mg}^{*} \mathrm{~h} * \mathrm{~mL}^{-1}\right), \mathrm{AUC}_{0 \text {-inf }}\left(0.95-1.16 \mathrm{mg}^{*} \mathrm{~h}^{*} \mathrm{~mL}^{-1}\right)$ and $\mathrm{C}_{\max }\left(0.92-1.12 \mathrm{mg}^{*} \mathrm{~h} * \mathrm{~mL}^{-1}\right)$ are within the $0.80-1.25$ interval proposed by the ANVISA and FDA. It was concluded that the test formulation (indinavir $400 \mathrm{mg}$ capsules) and the reference formulation (Crixivan ${ }^{\circledR} 400 \mathrm{mg}$ capsules) are bioequivalent.

\section{ACKNOWLEDGEMENTS}

The authors are grateful to Miracy Muniz de Albuquerque, Ph.D., and Eduardo de Jesus, Ph.D., for their support on the accomplishment of this study.

\section{RESUMO}

\section{Determinação de indinavir em plasma humano e sua aplicação em estudo farmacocinético}

Foi desenvolvido e validado um novo método, sensivel, exato e preciso por Cromatografia a Líquido de Alta Eficiência com detecção em UV para a determinação do sulfato de indinavir (IND) em plasma humano. Ofármaco foi extraido do plasma através de extração líquido-líquido obtendo recuperação média de $73.9 \%$, com limite inferior de quantificação de $0.05 \mu \mathrm{g} / \mathrm{mL}$. O método foi aplicado em estudo de farmacocinética para verificar a bioequivalência entre um novo medicamento genérico e seu produto de referência. A bioequivalência entre os pro- dutos foi determinada calculando-se um intervalo de confiança (IC) de $90 \%$ para a razão das médias do produto teste e referência compreendidas entre o intervalo de 0.80 1.25 proposto pela ANVISA e O FDA. Os produtos estudados são bioequivalentes e, portanto, intercambiáveis.

UNITERMOS: Indinavir/estudo farmacocinético. Plasma. Medicamentos genéricos/política.

\section{REFERENCES}

AYMARD, G.; LEGRAND, M.; TRICHEREAU, N.; DIQUET, B. Determination of twelve antiretroviral agents in human plasma sample using reversed-phase highperformance liquid chromatography. $J$ Chromatog. $B$, v.744, n.2, p. 227-240, 2000.

BURGER, D.M.; DE GRAAFF, M.; WUIS, E.W.; KOOPMANS, P.P.; HEKSTER, Y.A. Determination of indinavir, an HIV-protease inhibitor, in human plasma by reversed-phase high-performance liquid chromatography. J. Chromatogr., B, v.703, n.1/2, p.235-241, 1997.

CHI, J.; JAYEWARDENE, A.L.; STONE, J.A.; MOTOYA, T.; AWEEKA, F.T.; J. Simultaneous determination of five HIV protease inhibitors nelfinavir, indinavir, ritonavir, saquinavir and amprenavir in human plasma by LC/MS/ MS. J. Pharm. Biomed. Anal., v.30, n.3, p.675-684, 2002. 
DAILLY, E.; THOMAS, L.; KERGUERIS, T.M.F.; JOLLIET, P.; BOURIN, M. High-performance liquid chromatographic assay to determine the plasma levels of HIV-protease inhibitors (amprenavir, indinavir, nelfinavir, ritonavir and saquinavir) and the non-nucleoside reverse transcriptase inhibitor (nevirapine) after liquid-liquid extraction. J. Chromatogr., B, v.758, n.2, p.129-135, 2001.

FOISY, M.L.; SOMMADOSSI, J.P. Rapid quantification of indinavir in human plasma by high-performance liquid chromatography with ultraviolet detection. $J$. Chromatogr., B, v.721, n.2, p.239-247, 1999.

HAAS, D.W.; STONE, J.; CLOUGH, L.A.; JOHNSON, B.; SPEARMAN, P.; HARRIS, V.L.; NICOTERA,J.; JOHNSON, R.H.; RAFFANTI, S.; ZHONG, L.; BERGQWIST, P.; CHABERLIN, S.; HOAGLAND, V.D.; JU, W. Steady-state pharmacokinetics of Indinavir in cerebrospinal fluid and plasma among adults with human immunodeficiency virus type 1 infection. J. Clin. Pharm. Ther., v.68, n. p.367-374, 2000.

HUGEN, P.W.H.; VERWEIJ-VAN, C.P.W.G.M.; BURGER, D.M.; WUIS, E.W.; KOOPMANS, P.P.; HEKSTER, Y.A. Simultaneous determination of the HIV-protease inhibitors indinavir, nelfinavir, saquinavir and ritonavir in human plasma by reversed-phase high-performance liquid chromatography. J. Chromatogr., B, v.727, n.1/2, p.139149, 1999.

HURWITZ, S.J.; SCHINAZI, R.F. Development of a pharmacodynamic model for HIV treatment with nucleoside reverse transcriptase and protease inhibitors. Antiviral Res., v.56, n.2, p.115-127, 2002.

JAYEWARDENE, A.L.; ZHU, F.; AWEEKA, F.T.; GAMBERTOGLIO, J.G. Simple high-performance liquid chromatographic determination of the protease inhibitor Indinavir in human plasma. J. Chromatogr., B, v.707, n.1/ 2, p.203-211, 1998.

JAYEWARDENE, A.L.; KEARNEY, B.; STONE, J.A.; GAMBERTOGLIO, J.G.; AWEEKA, F.T. An LC-MSMS method for the determination of indinavir, an HIV-1 protease inhibitor, in human plasma. J. Pharm. Biomed. Anal., v.25, n.2, p.309-317, 2001.
JUSTESEN, U.S.; PEDERSEN, C.; KLITGAARD, N.A. Simultaneous quantitative determination of the HIV protease inhibitors indinavir, amprenavir, ritonavir, lopinavir, saquinavir, nelfinavir and the nelfinavir active metabolite M8 in plasma by liquid chromatography. $J$. Chromatogr., B, v.783, n.2, p.491-500, 2003.

LANGMANN, P.; KLINDER, H.; SCHIRMER, D.; ZILLY, M.; RICHTER, E. High-performance liquid chromatographic method for the simultaneous determination of HIV-1 protease inhibitors indinavir, saquinavir and ritonavir in plasma of patients during highly active antiretroviral therapy. J. Chromatogr., $B$, v.735, n.1, p.41-50, 1999.

LIN, J.H. Role of pharmacokinetics in the discovery and development of Indinavir. Adv. Drug Delivery Rev., v.39, n.1/3, p.33-49, 1999.

LIN, J.H. Human immunodeficiency virus protease inhibitors from drug design to clinical studies. Adv. Drug Delivery Rev., v.27, n.2/3, p.215-233, 1997.

MARZOLINI, C.; BÉGUIN, A.; TELENTI, A.; SCHREYER, A.; BUCLIN, T.; BIOLLAZ, J.; DECOSTERD, L.A. Determination of lopinavir and nevirapine by high-performance liquid chromatography after solid-phase extraction: application for the assessment of their transplacental passage at delivery. J. Chromatogr., $B$, v.774, n.2, p.127-140, 2002.

MEGARD, I.; GARRIGUE, A.; ORLOWSKI, S.; JORAJURIA, S.; CLAYETTE, P.; EZAN, E.; MABONDZO, A. A co-culture-based model of human blood-brain barrier: application to active transport of indinavir and in vivo-in vitro correlation. Brain Res., v.927, n.2, p.153-167, 2002.

RAFFANI, S.; HAAS, D. W. Antimicrobianos: Agentes antiretrovirais. In: Goodman \& Gilman. As bases farmacológicas da terapêutica. 10.ed. Rio de Janeiro: Mc Graw-Hill, 2003. cap. 51, p.1024-1025

RENTSCH, K.M. Sensitive and specific determination of eight antiretroviral agents in plasma by high-performance liquid chromatography-mass spectrometry. $J$. Chromatogr., B, v.788, n.2, p.339-350, 2003. 
ROSE, M.J.; MERSCHMAN, S.A.; EISENHANDLER, R.; WOOLF, E.J.; YEH, K.C.; LIN, L.; FANG, W.; HSIEH, J.; BRAUN, M.P.; GATTO, G.J.; MATUSZEWSKI, B. High-throughput simultaneous determination of the HIV protease inhibitors indinavir and L-756423 in human plasma using semi-automated 96-well solid phase extraction and LC-MS:MS. J. Pharm. Biomed. Anal., v.24, n.2, p.291-305, 2000.

SARASA-NACENTA, M.; LÓPEZ-PÚA, Y;; MALLOLAS, J.; BLANCO, J.L.; GATELL, J. M.; CARNÉ, X.; Simultaneous determination of the HIV-protease inhibitors indinavir, amprenavir, ritonavir, saquinavir and nelfinavir in human plasma by reversed-phase high-performance liquid chromatography. J. Chromatogr., B, v.757, n.2, p.325-332, 2001.

SCHÖN, A.; INGARAMO, M. DEL M.; FREIRE, E. The binding of HIV-1 protease inhibitors to human serum proteins. Biophys. Chem., v.105, n.2/3, p.221-230, 2003.

STORPIRTIS, S.; OLIVEIRA, P.G.; RODRIGUES, D.; MARANHÃO, D. Considerações biofarmacotécnicas relevantes na fabricação de medicamentos genéricos: fatores que afetam a dissolução e absorção dos fármacos. Rev. Bras. Cienc. Farm., v.35, n.1, p.1-16, 1999.

SVENSSON, J.O.; SONNERBORG, A.; STAHLE, L. Rapid and Simple determination of Indinavir in serum, urine and cerebrospinal fluid using high-performance liquid chromatography. Ther. Drug Monit., v.22, n.5, p.626-629, 2000.

TURNER, M.L.; REED-WALKER, K.; KING, J.R.; ACOSTA, E.P. Simultaneous determination of nine antiretroviral compounds in human plasma using liquid chromatography. J. Chromatogr., B, v.784, n.2, p.331$341,2003$.
VAN HEESWIJK, R.P.G.; HOETELMANS, R.M.W.; HARMS, R.; MEENHORST, P.L.; MULDER, J.W.; LANGE, J.M.A.; BEIJNEN, J.H. Simultaneous quantitative determination of the HIV protease inhibitors amprenavir, indinavir, nelfinavir, ritonavir and saquinavir in human plasma by ion-pair high-performance liquid chromatography with ultraviolet detection. $J$. Chromatogr., B, v.719, n.1/2, p.159-168, 1998.

VILLANI, P.; FEROGGIO, M.; GIANELLI, L.; BARTOLI, A.; MONTAGNA, M.; MASERATI, R.; REGAZZI, M.B.Antiretrovirals: Simultaneous determination of five protease inhibitors and three nonnucleoside transcriptase inhibitors in human plasma by a rapid high-performance liquid chromatography-mass spectrometry assay. Ther. Drug Monit., v.23, n.4, p.380-388, 2001.

WOOLF, E.; HADDIX, H.M.; MATUSZEWSKI, B. Determination of an in vivo metabolite of a human immunodeficiency virus protease inhibitor in human plasma by high-performance liquid chromatography with tandem mass spectrometry. J. Chromatogr., A, v.762, n.1/ 2, p.311-319, 1997.

ZHONG, L.; YEH, K.C. Determination of indinavir in human cerebrospinal fluid and plasma by solid-phase extraction and high-performance liquid chromatography with column switching. J. Chromatogr., B, v.734, n.1, p.63-71, 1999.

YAMADA, H.; KOTAKI, H.; NAKAMURA, T.; IWAMOTO, A. Simultaneous determination of the HIV protease inhibitors indinavir, amprenavir, saquinavir, ritonavir and nelfinavir in human plasma by highperformance liquid chromatography, $J$. Chromatogr., $B$, v.755, n.1/2, p.85-89, 2001.

YEH, K.C.; STONE, J.A.; CARIDE, A.D.; ROLAN, P.; WOOLF, E.D.; JU, W. Simultaneous investigation of indinavir nonlinear pharmacokinetics and bioavailability in healthy volunteers using stable isotope labelling technique: study design and model-independent data analysis. J. Pharm. Sci., v.88, p.5, 1999.

Recebido para publicação em 17 de novembro de 2006. Aceito para publicação em 17 de setembro de 2007. 